to increase our understanding of the response of marine microbial ecosystems to climate change. Given the strong evidence, however, that we are fundamentally changing Earth's 'heart and lungs', there is no longer any excuse for international community not to pursue deep and rapid cuts in the use of fossil fuels and other greenhouse gas emitting sources. If we continue to ignore this evidence, we will place our planet, and the future of ourselves and our children, in extreme jeopardy.

O Hoegh-Guldberg is Director of the Global Change Institute, University of Queensland, St Lucia, Queensland, Australia

E-mail: oveh@uq.edu.au (www.coralreefecosystems.org; www.climateshifts.org)

\section{References}

Arrigo K. (2005). Marine microorganisms and global nutrient cycles. Nature 437: 349-355.

Behrenfeld M, O’Malley R, Siegel D, McClain C, Sarmiento J, Feldman G et al. (2006). Climate-driven trends in contemporary ocean productivity. Nature 444: 752-755.

Bindoff NL, Willebrand J, Artale V, Cazenave A, Gregory J, Gulev S et al. (2007). Observations: oceanic climate change and sea level. In: Solomon S, Qin D, Manning M, Chen Z, Marquis M, Averyt K, Tignor M and Miller $\mathrm{H}$ (eds). In Climate Change 2007: The Physical Science Basis. Contribution of Working Group I to the Fourth Assessment Report of the Intergovernmental Panel on Climate Change. Cambridge University Press: Cambridge, UK and New York, NY, USA.

Church J, White N. (2006). A 20th century acceleration in global sea-level rise. Geophys Res Lett 33: L01602.

Diaz R, Rosenberg R. (2008). Spreading dead zones and consequences for marine ecosystems. Science 321: 926.

Doney S, Fabry V, Feely R, Kleypas J. (2009). Ocean acidification: the other $\mathrm{CO}_{2}$ problem. Annu Rev Marine Sci 1: 169-192.
Field C, Behrenfeld M, Randerson J, Falkowski P. (1998). Primary production of the biosphere: integrating terrestrial and oceanic components. Science 281: 237-241.

Gregg W, Conkright M, Ginoux P, O’Reilly J, Casey N. (2003). Ocean primary production and climate: global decadal changes. Geophys Res Lett 30: 1809.

Hoegh-Guldberg O, Bruno JF. (2010). The impact of climate change on the world's marine ecosystems. Science 328: 1523-1528.

Hoegh-Guldberg O, Mumby PJ, Hooten AJ, Steneck RS, Greenfield P, Gomez E et al. (2007). Coral reefs under rapid climate change and ocean acidification. Science 318: 1737-1742.

Hoegh-Guldberg O, Pearse JS. (1995). Temperature, food availability, and the development of marine invertebrate larvae 1. Integr Comp Biol 1995.

IPCC (2007). Synthesis report. Contribution of Working Groups I, II and III to the Fourth Assessment Report of the Intergovernmental Panel on Climate Change, CW Team, RK Pachauri and A Reisinger (eds). Intergovernmental Panel on Climate Change: Geneva, Switzerland.

Meinshausen M, Meinshausen N, Hare W, Raper S, Frieler $\mathrm{K}$, Knutti R et al. (2009). Greenhouse-gas emission targets for limiting global warming to $2^{\circ} \mathrm{C}$. Nature 458 : 1158-1162.

McNeil B, Matear R. (2008). Southern Ocean acidification: a tipping point at 450-ppm atmospheric $\mathrm{CO}_{2}$. Proc Natl Acad Sci 105: 18860-18864.

Naish T, Powell R, Levy R, Wilson G, Scherer R, Talarico F et al. (2009). Obliquity-paced Pliocene West Antarctic ice sheet oscillations. Nature 458: 322-328.

Pollard D, DeConto R. (2009). Modelling West Antarctic ice sheet growth and collapse through the past five million years. Nature 458: 329-332.

Polovina J, Howell E, Abecassis M. (2008). Ocean's least productive waters are expanding. Geophys Res Lett 35: L03618.

Rockström J, Steffen W, Noone K, Persson A, Chapin F, Lambin E et al. (2009). A safe operating space for humanity. Nature 461: 472-475.

Ward P. (2007). Under a Green Sky: Global Warming. The Mass Extinctions of the Past, and What they Mean for our Future. Smithsonian Books/Collins: New York.

Wegner C, Forest A, Forwick M, Frey K, Mathis J, Michel C et al. (2010). Arctic in rapid transition. Arctic Ocean Sciences Board/International Arctic Science Committee (AOSB/IASC), $34 \mathrm{pp}$.

\title{
Ammonia oxidation: different niches for bacteria and archaea?
}

\author{
Christa Schleper
}

The ISME Journal (2010) 4, 1092-1094; doi:10.1038/ ismej.2010.111; published online 15 July 2010

Ammonia oxidation, the first step of nitrification, has been known to be performed by certain groups of chemolithoautotrophic proteobacteria for more than a hundred years. The recent discovery of homologs of ammonia monooxygenase genes in archaea and the cultivation of archaeal ammonia oxidizers has radically changed this view, indicating 
that an additional, quite predominant group of microorganisms is able to perform this process.

Based on the distribution of archaeal amoA and 16SrRNA genes, it seems that archaea with the potential capacity to oxidize ammonia (AOA) are found in almost every environment on Earth, including ocean waters, estuaries, sediments and soils, hot springs, the guts of animals, plant leaves, and even in the ultra-clean rooms of NASA (Moissl et al., 2008). Astonishingly, estimates based on gene counts (quantitative polymerase chain reaction) indicate that AOA, which have been overlooked for so many years, outnumber ammoniaoxidizing bacteria (AOB) in most environments, often even by orders of magnitude.

Many questions arise from these studies, as very little is known about the physiology of ammonia-oxidizing archaea. Do they really extensively contribute to nitrification on this planet as their sheer numbers might suggest? Are they all chemolithoautotrophs like probably most of their bacterial counterparts, growing exclusively on inorganic carbon and nitrogen? Or is their metabolism perhaps more versatile, as they are so abundant in many different environments? Do bacterial and archaeal ammonia oxidizers compete for the same resources, that is, are they functionally redundant or do they rather occupy different niches?

As maxima of nitrite and nitrate production in the oceanic water column have been shown to correlate positively with amoA genes of archaea and with archaeal cell counts (for example, Wuchter et al., 2006), it is assumed that AOA indeed perform the bulk ammonia oxidation in the oceanic plankton. In contrast, no such correlation was found earlier between the dynamics of bacterial ammoniaoxidizing populations and nitrification rates. In line with these findings are physiological studies of the only marine cultivated isolate of ammonia-oxidizing archaea, Nitrosopumilus maritimus (Martens-Habbena et al., 2009). The organism appears to be adapted to very low amounts of its substrate ammonia. Both its extremely low substrate threshold and its halfsaturation constant are unprecedented, but coherent with the conditions in the oligotrophic open ocean. In total, these studies strongly indicate that certain lineages of ammonia-oxidizing archaea contribute to a large extent to the nitrogen cycling in the ocean.

The situation is not so clear in terrestrial environments, as conflicting results have been reported when nitrification rates in soils were directly analyzed in the context of both $\mathrm{AOB}$ and $\mathrm{AOA}$ populations. Jia and Conrad (2009) saw growth of AOB in an agricultural soil in response to amendment of inorganic fertilizer that correlated with ammonia oxidation activity. AOA growth, however, seemed to be independent of nitrification and, in contrast to AOB, the archaea did not incorporate 13-C-labelled bicarbonate, indicating incorporation of organic carbon rather than an autotrophic growth mode. In contrast, in one out of two agricultural soils analyzed by Schauss et al. (2009), growth of amoA-containing archaea was demonstrated in response to added organic fertilizer. On addition of the antibiotic sulfadiazine that inhibited growth of AOB, nitrification seemed to be taken over by AOA. A different outcome again was seen in the studies of soils in New Zealand also amended with organic fertilizer. Di et al. (2009) found a positive correlation between nitrification and growth of AOB only. The population of archaea increased in control soils with low nitrogen load and low nitrification rates (Di et al., 2010). In a series of elegant experiments, colleagues from Aberdeen demonstrated the growth and nitrification activity of AOA in soils, again under conditions of no external nitrogen input (Tourna et al., 2008; Offre et al., 2009). The activity of AOA varied in mesocosms of different temperatures in parallel to changes in nitrification activity. Furthermore, growth of this transcriptionally active population was inhibited upon addition of low amounts of acetylene, which also inhibited nitrification. However, phylogenetic analyses showed that the active archaeal population in this particular soil was associated with the 'marine' group of AOA, often referred to as group I.1a, whereas a second clearly distinct group (group I.1b) is found in the majority of soils that have been investigated in different countries and on different continents. Thus, these particular experiments do not allow extrapolation to the physiology of the dominating lineage of AOA in soil. No study appears to have been able yet to clearly link ammonia-oxidizing activity in a natural environment to group I.1b archaea, although considerable amounts and a large diversity of amoA genes of this group have been identified in a diverse range of soils (Leininger et al., 2006) and transcriptional activity and growth suggests their metabolic activity. It is just quite possible that group I.1b exhibits a broader range of metabolism and adaptations and that organisms of this group might effectively compete with AOB or other bacteria in soils and other environments. Only laboratory cultures of AOA from soil as well as further careful molecular environmental studies will help to elucidate the physiological diversity and ecosystem functioning of this enigmatic group of archaea.

Nevertheless, all three cultured representatives of ammonia-oxidizing archaea are adapted to low ammonia concentrations. In addition, the occurrence and activity of AOA in hot springs, in pristine environments, in deeper soil layers and in soils of low $\mathrm{pH}$ all suggest that many ammonia-oxidizing archaea are adapted to extreme growth conditions and to substrate concentrations that are considerably lower than those consumable by known cultured AOB species, thus indicating a niche separation between AOA and AOB.

C Schleper is at Department of Genetics
in Ecology, University of Vienna,
Vienna, Austria
E-mail: christa.schleper@univie.ac.at




\section{References}

Di H, Cameron K, Shen J, Winefield C, O’Callaghan M, Bowatte $\mathrm{S}$ et al. (2010). Ammonia-oxidizing bacteria and archaea grow under contrasting soil nitrogen conditions. FEMS Microbiol Ecol 72: 386-394.

Di HJ, Cameron KC, Shen JP, Winefield CS, O'Callaghan $\mathrm{M}$, Bowatte $\mathrm{S}$ et al. (2009). Nitrification driven by bacteria and not rchaea in nitrogen-rich grassland soils. Nat Geosci 2: 621-624.

Jia Z, Conrad R. (2009). Bacteria rather than archaea dominate microbial ammonia oxidation in an agricultural soil. Environ Microbiol 11: 1658-1671.

Leininger S, Urich T, Schloter M, Schwark L, Qi J, Nicol GW et al. (2006). Archaea predominate among ammonia-oxidizing prokaryotes in soils. Nature 442: 806-809.

Martens-Habbena W, Berube PM, Urakawa H, de la Torre JR, Stahl DA. (2009). Ammonia oxidation kinetics determine niche separation of nitrifying archaea and bacteria. Nature 461: 976-979.

Moissl C, Bruckner JC, Venkateswaran K. (2008). Archaeal diversity analysis of spacecraft assembly clean rooms. ISME J 2: 115-119.

Offre P, Prosser JI, Nicol G. (2009). Growth ofammoniaoxidizing archaea in soil microcosms is inhibited by acetylene. FEMS Microbiol Ecol 70: 99-108.

Schauss K, Focks A, Leininger S, Kotzerke A, Heuer H, Thiele-Bruhn S et al. (2009). Dynamics and functional relevance of ammonia-oxidizing archaea in two agricultural soils. Environ Microbiol 11: 446-456.

Tourna M, Freitag TE, Nicol GW, Prosser JI. (2008). Growth, activity and temperature responses of ammonia-oxidizing archaea and bacteria in soil microcosms. Environ Microbiol 10: 1357-1364.

Wuchter C, Abbas B, Coolen MJ, Herfort L, van Bleijswijk J, Timmers $\mathrm{P}$ et al. (2006). Archaeal nitrification in the ocean. Proc Natl Acad Sci USA 103: 12317-12322.

\section{Creating and characterizing communities of human gut microbes in gnotobiotic mice}

Jeremiah J Faith*, Federico E Rey*, David O’Donnell, Maria Karlsson, Nathan P McNulty, George Kallstrom, Andrew L Goodman and Jeffrey I Gordon

The ISME Journal (2010) 4, 1094-1098; doi:10.1038/ ismej.2010.110; published online 22 July 2010

Microbiology laboratories are laden with flasks, plates, and freezer stocks containing axenic cultures and their products. In contrast, virtually every other habitat on Earth is filled with microbial communities of varying degrees of complexity. In this context, microorganisms are interdependent components of ecosystems; deciphering this dynamic requires a move from microbial organisms studied in isolation to model microbial communities studied under conditions that mimic those encountered by their members in their native habitats. Here, we focus on model communities consisting of microbes that inhabit the human body habitat containing our largest collection of organisms-the gut.

The adult human gastrointestinal tract is a microbial bioreactor, containing all three domains of life. This ecosystem is teeming with microorganisms at its distal end $\left(10^{11}-10^{12}\right.$ cells $\mathrm{ml}^{-1}$ luminal contents in the colon) and less so at its proximal end (an estimated $10^{3}$ $10^{4}$ cells ml ${ }^{-1}$ luminal contents in the duodenum). The gut microbiota affects myriad aspects of our systems physiology, ranging from processing and harvesting of macronutrients and micronutrients (and xenobiotics!) from our diets, to shaping the features of our innate and adaptive immune system. Recently, deep sampling of the fecal microbial community has revealed that each of us harbor a collection of a several hundred bacterial phylotypes (Qin et al., 2010; Turnbaugh et al., 2010). The exact set of microbes differs from person to person although there is a greater degree of similarity between family members (Turnbaugh et al., 2009a, 2010). A catalog of several million genes present in the fecal microbiome has been assembled from analysis of a 577Gbp data set obtained from shotgun sequencing of fecal community DNA prepared from 124 Europeans (Qin et al., 2010) and a 10.1-Gbp data set generated from a set of deeply sampled obese monozygotic co-twins living in the United States (Turnbaugh et al., 2010). These data sets provide a starting point for making in silico predictions about functions that can be attributed to the gut microbiota. Measurements of expressed mRNAs (Turnbaugh et al., 2010), proteins (Verberkmoes et al., 2009), and metabolites (Hoverstad et al., 1984; Li et al., 2008; Martin et al., 2008) in gut samples represent a first step toward testing these predictions.

\section{Generating germ-free mice via embryo transfer}

Germ-free (GF) mice provide a complementary approach for characterizing the properties of the human gut microbiome. Methods for establishing and 